\title{
WORKPLACE WELLBEING AND BURNOUT SYNDROME: OPPOSITE FACES IN PENITENTIARY WORK
}

\author{
JONATHAN S. CORRÊA ${ }^{1}$ \\ (iD) https://orcid.org/0000-0003-3705-2886 \\ LUIS F. D. LOPES \\ (iD) https://orcid.org/0000-0002-2438-0226 \\ DAMIANA M. ALMEIDA ${ }^{3}$ \\ (iD) https://orcid.org/0000-0001-6433-9212 \\ MARIA E. CAMARGO 4 \\ (iD) https://orcid.org/0000-0002-3800-2832
}

To cite this paper: Corrêa, J. S., Lopes, L. F. D., Almeida, D. M., \& Camargo, M. E. (2019). Workplace wellbeing and Burnout Syndrome: Opposite faces in penitentiary work. Revista de Administração Mackenzie, 20(3). doi:10.1590/1678-6971/eRAMG190149

Submission: Sept. 11, 2018. Acceptance: Nov. 22, 2018.

1 Fundação Universidade Federal do Pampa (Unipampa), Alegrete, RS, Brazil.

2 Federal University of Santa Maria (UFSM), Santa Maria, RS, Brazil.

3 Faculty of Health Sciences (SOBRESP), Santa Maria, RS, Brazil.

4 University de Caxias do Sul (UCS), Caxias do Sul, RS, Brazil.

\section{(cc) BY




\section{ABSTRACT}

Purpose: The objective of this study was to analyze the perspectives of correctional officers of the State of Rio Grande do Sul to understand the relationship between the components of workplace wellbeing and the incidence of Burnout Syndrome.

Originality/value: Professionals in the area of public safety live daily with a plurality of feelings since they carry out social services in conditions assumed to produce high levels of stress. We recruited participants the Superintendency of Penitentiary Services of the State of Rio Grande do Sul (Susepe), a work environment, chosen to investigate the opposing faces of workplace wellbeing and Burnout Syndrome in the daily lives of penitentiary workers.

Design/methodology/approach: We combined a descriptive survey design with a quantitative analytic approach. The sample was nonprobabilistic, comprised of 433 respondents.

Findings: The results indicated that workplace wellbeing is partially present in the daily life of the penitentiary workers, being that no work stress and Burnout Syndrome were evidenced. As for the correlations between the constructs, they all proved to be significant. The results revealed four significant associations between the levels of the workplace wellbeing and indicators of Burnout Syndrome.

\section{KEYWORDS}

Organizational behavior. Workplace wellbeing. Burnout Syndrome. Penitentiary workers. Susepe. 


\section{INTRODUCTION}

Positive and negative aspects of the work routine can interfere directly in the individual performance of service workers. Positive aspects are characteristics of the job that foster feelings of workplace wellbeing. Dessen and Paz (2010) affirm that workplace wellbeing can be defined as meeting the pretensions of professionals in the workplace. However, aspects of work which impact negatively tend to be harmful to health, leading to problems such as work stress and Burnout Syndrome. According to Carvalho and Magalhães (2011, p. 204) "Burnout usually leads to deterioration of physical and emotional well-being".

Depending on the activity, the experience of feelings is even more intense, as in the work environment of the Superintendence of Penitentiary Services of the State of Rio Grande do Sul, where characteristics of the work environment are more difficult than those of most other professions. In working to bring about the social reintegration of prisoners, the penitentiary worker plays a fundamental role in the security of society. The Constitution of the State of Rio Grande do Sul establishes, in its article 137, the re-education, social reintegration and re-socialization of prisoners (Rio Grande do Sul, 2009), as objectives of penitentiary programs. For researchers, investigating organizational behavior in the public safety environment is a challenge, given the complexity of the work system and environment.

In the daily performance of their functions, people working in prison environments routinely face dangerous situations that carry the potential for physical and mental damage or even death (Rumin, 2006; Justo \& BenevidesPereira, 2011; Kaur, Chodagiri, \& Reddi, 2013; Tschiedel \& Monteiro, 2013; Weltman et al., 2014). This context is exacerbated by the current situation within the prison system in Brazil, of inadequate numbers of penitentiary workers (Ministério Público, 2016), as well as the government policy within the State of Rio Grande do Sul dividing server salaries (Jacobsen, 2017).

Although employment in the prison system is generally seen in a derogatory light, the presumption that workers' experience is unanimously negatively is inaccurate. Factors such as government policies, infrastructure, and people management can positively influence the work environment. In addition, prison staff is involved in daily social projects related to the rehabilitation of prisoners. Worker involvement in these projects and the experience of aiding the resocialization of inmates can bring positive meaning to their work. For example, Bonez, Dal Moro, and Sehnem (2013) 
found that prison agents demonstrated good mental health and low levels of stress, in addition to showing satisfaction with their labor.

In this study, we collected the perspectives of the correctional officers of the State of Rio Grande do Sul on their experience of and response to the work environment to analyze the relationship between those components that favor workplace wellbeing and indicators of Burnout Syndrome. To do so, we measured the levels of both dimensions using selected constructs in self-report surveys. We then performed correlational analyses of the work welfare constructs with those of Burnout Syndrome to associate the score levels of the constructs.

Botelho and Paiva (2011) point out that the peculiarities of the public sector increase the relevance of welfare research because, unlike the private sector, the public administration is concerned with the interests of the population. Therefore, it follows that the achievement of acceptable standards of physical and mental health among prison staff serves the public interest. It should be mentioned that a literature search carried out on the subjects workplace wellbeing and Burnout Syndrome revealed no national or international studies investigating the relationship between these two themes in the context of penitentiary servers.

The results of this study can be used to guide institutional strategies to improve workplace wellbeing. Consequently, potential benefits to be gained from institutional actions applying the results found in the State of Rio Grande do Sul in other states suggest the usefulness of benchmarking other prisons. We offer the results of the present study to guide the development of strategies aimed at minimizing the physical and psychological risks of working in penitentiary environments while maximizing workplace wellbeing.

\section{WORKPLACE WELLBEING}

The first theories on Welfare were directed towards the economy, with this usage, being a synonym for income. By the early 60's this application had been transcended to address quality of life (Galinha \& Ribeiro, 2005; Siqueira \& Padovam, 2008). Later, in the 70's with the emergence of a movement based mainly in the United States, welfare acquired characteristics of health problem-solving (Galinha \& Ribeiro, 2005), on to address the psychological health of individuals (Ryan \& Deci, 2001). This change in the concept of Welfare caused theoretical conflicts, which, according to 
Novo (2003) led to the emergence of two distinct currents in the 80's: Subjective Well-Being (SWB) and Psychological Well-Being (PWB), with "the main difference between them being 1 in the conception of happiness adopted" (Paschoal \& Tamayo, 2008, p. 12).

Subjective Well-Being is related to philosophical hedonism, being synonymous with pleasure and happiness (Ryan \& Deci, 2001). Albuquerque and Trócolli (2004) describe SWB using three dimensions: positive affect, negative affect, and satisfaction with life. Paschoal and Tamayo (2008) reinforce that welfare characterized by hedonic happiness can be considered basically as a state in which positive effects prevail over negative ones. The goal of investigations in SWB is thus to understand the assessments that people make of their own lives in relation to affective aspects (Diener, Suh, \& Oishi, 1997).

By contrast, Psychological Well-Being, according to Ryan and Deci (2001), is supported by eudaemonism, which bases the perception of Welfare on the realization of personal potential The proponents of this theory "appear as critics of the fragility of the formulations that underpinned SWB" (Siqueira \& Padovam, 2008, p. 205). According to these authors, while SWB encompasses satisfaction with life under a prism of positive and negative affect that generates happiness, PWB relies on psychological formulations related to human development and the ability of each individual to face challenges.

In agreement, Paschoal and Tamayo (2008) and Argolo and Araújo (2004) reinforce the conception that the sense of wellbeing that comes from personal fulfillment is reflected in the perception of advancement in the pretensions of life. It follows that analyses of work wellbeing that take into account only one of these currents - SWB or PWB - is incomplete since these two contributions are complementary. Galinha and Ribeiro (2008, p. 209) state that:

The studies on Subjective Well-Being are developed in parallel, and often in articulation with the concepts of Psychological Well-Being, within an even greater field that is that of health in general and Mental Health in particular. The separation of Psychological Well-Being and Subjective Well-Being becomes, for these reasons, essential to respect the limits of concepts.

Aside from contributing to the evolution of the concept of general wellbeing over the decades, these two concepts have been also used in studies 
on Welfare in Work. According to Accardo (2013, p. 35), "well-being in the workplace is a fundamental element to live well, because, in general, people usually spend much of their lives dedicating themselves to work".

Relying on the theoretical contributions of both the SWB and PWB currents, that is, by harmonizing the dimensions of affective response with development of potentialities, it is possible to address the complexity inherent in the experience of workplace wellbeing. In addition to the work factors, the personal ones can also influence workplace wellbeing, since these directly influence the humor and the happiness of the individual. Indeed, Rothbard and Edwards (2000), show that institutions have tried to adopt strategies aimed at understanding the influence of workers' personal lives on their work activities. Through such actions, institutions have demonstrated an interest in acknowledging the unique problems of each worker, in order to take steps to increase workers' well-being.

Although there are multiple definitions of workplace wellbeing, Paschoal (2008) elucidates that in most research the concept is confused with happiness. In the present study we adopted the concept of Paschoal de Tamayo (2008), also corroborated by Waterman Schwartz and Conti (2008), which defines workplace wellbeing as the predominance of positive emotions at work and the individual's perception that he/she is able to develop his/ her potential and to advance in the attainment of life goals.

Sonnentag (2002) argues that workers with high job satisfaction are more productive. Hakanen, Perhoniemi, and Toppinem-Tanner (2008) corroborate this, finding that individuals with higher well-being and satisfaction show more initiative. Workplace wellbeing has also been considered essential for promoting competitiveness among institutions, especially regarding the positive experiences of the worker (Sant'anna, Paschoal, \& Gosendo, 2012), since the productivity of the individual depends on his physical and psychological state.

This acknowledgment of the requirements for productivity implies the consolidation of SWB and PWB in the understanding of workplace wellbeing. This broader definition has been used in a variety of organizational contexts (Paschoal \& Tamayo, 2008) and necessitates appropriate tools that allow the collection of data describing the behavioral aspects of individuals.

In addressing workplace wellbeing, researchers tend to relate it to positive factors, such as job satisfaction, or negative elements, such as stress and Burnout Syndrome (Siqueira \& Padovam, 2008). An important theme commonly explored in research on Welfare at Work is how engagement at work relates to Burnout Syndrome (Schaufeli, Bakker, \& Salanova, 2006). 
Makikangas and Kinnunen (2003) showed that stressful conditions at work negatively impact an individual's optimism and self-esteem, compromising their perception of workplace wellbeing. Santos and Cubas (2012) also affirm that occupational stress is directly related to the effort spent in the adaptation to inadequate environments, that is, the physical and mental wear and tear caused by the performance of activities in the presence of precarious conditions. Thus, when measuring workplace wellbeing, it is necessary to analyze the negative aspects in addition to the positive ones, since this two interact.

\section{BURNOUT SYNDROME}

Early definitions of work 'stress' come from the seventeenth century, but it was not until 1926 that one of the main scholars on the subject, Hans Selye, described it as a state of tension in the organism (LIPP, 2000). Benevides-Pereira (2002) mentions that through the popularization of the definition of stress in general society, it became synonymous with any unusual negative behavior. The research realm the definition of stress is problematic because several areas of science - from the biological sciences to the social and human sciences - use the term for different objects of study, the. As Faro and Pereira (2013) note, the different themes in the literature may refer variously to stressors, cognitive mediation, or health consequences. Stress is a state in which the body emits reactions to various environmental, physical and social situations (Ferraz, Francisco, \& Oliveira, 2014). In other words, when the homeostasis of the individual is compromised, the body emits responses aimed at restoring internal balance.

It is important to note that not all types of stress can be considered harmful. Bianchi (2001) argues that stress can also adopt positive connotations, such as when the individual perceives the stressful event as a challenge. Sonnentag and Bayer (2005) also confirm that not every workload leads to stress, but rather that chronic and permanent work routine. According to Bonez, Dal Moro, and Sehnem (2013, p. 514) "it is natural and even expected that the human being experiences some occasional discomfort, which is similar to the symptoms of stress". Abreu et al. (2002) indicate that both the presence or absence of stress can be harmful, but prolonged stress at work tends to lead to occupational diseases.

In certain cases, the recurrence of high occupational stress situations leads to the development of more serious physical and mental problems. 
Monteiro, Dalagasperina, and Quadros (2012, p. 20) affirm that there are, "in addition to occupational stress, other occupational diseases caused by the recurrence and permanence of the same, among which stands out the Burnout Syndrome". Maslach and Jackson were pioneers in studying the theme, characterizing it as a problem coming from the work environment, and not from the individual (Neves, Oliveira, \& Alves, 2014). For this study, we adopt the concept established by Gil-Monte (2005), which defines Burnout Syndrome as a reaction to too much work stress, especially among those workers whose work revolves around interaction with other people.

In contrast to positive stress, Burnout Syndrome is always harmful to the professional and personal life (Benevides-Pereira, 2002). That is why, as Maslach and Jackson (1981) assert workers feel unhappy and dissatisfied with their achievements at work. As a result, organizations that seek greater efficiency must pay attention to at least the hygienic aspects of the work. According to Benevides-Pereira (2002), the symptoms of Burnout Syndrome can be physical, behavioral, psychic and defensive.

Burnout Syndrome is classified under Brazilian law as a work-related mental disorder, is considered a work accident (Costa et al., 2013). A typical risk factor is a difficult work schedule, with associated physical and mental difficulties (Brasil, 1999). According to article 19 of Law no. 8213/1991, a work accident arises during the performance of work duties, manifested as a bodily injury or a functional disturbance that results in death or reduces, permanently or temporarily, the individual's ability to work (Brasil, 1991).

Gil-Monte (2005) divides the burnout process into two profiles, suggesting that there is a specific order of presentation of the symptoms. The first profile (early symptoms) is linked to cognitive and effective damage which impairs the employee's performance of his or her functions; the second profile entails any secondary consequences of the first symptoms, such as feelings of guilt about previous actions. Gil-Monte confirms the existence of burnout only in the manifestation of the second phase, the first phase alone being considered merely occupational stress.

Maslach, Schaufelli, and Leiter (2001) argue that chronic daily stress on the job, excessive pressure, interpersonal conflicts and low recognition of symptoms are factors that promote Burnout Syndrome. In line with this assertion, Bakker and Demerouti (2013) contend that in certain cases, the availability of organizational resources is not commensurate with work demands, leading to the occurrence of burnout. Thus, because of the relationship between resource availability and burnout, this topic has transcended the academic field, arousing the interests of managers (Leiter, 
Baker, \& Maslach, 2014), seeking to minimize workforce illness and lowered productivity. Individual performance is also related to work engagement, which may act as a counter to Burnout Syndrome, as the associated energy and enthusiasm for the work can mitigate the stressful effects of the negative aspects (Schaufeli, Bakker, \& Salanova, 2006; Schaufeli, 2012).

Thus, the prevention of Burnout Syndrome is important to the quality of working life. On the other hand, it is important to point out that the identifying symptoms of burnout in one employee of an institution does not necessarily mean it is present in others since this disease follows a unique progression in each individual, and its effects can take years to become noticeable (Rudow, 1999). Consequently, Maslach (2003) argues that strategies to reduce the occurrence of burnout syndrome should not be targeted to individuals, but rather directly at the workplace, through preventive strategies.

For example, Almeida (2015) points out that in order to prevent the incidence of stressful situations it is necessary to alter the structure and routines of the institutions. Therefore, it is possible to infer the ideal strategy and implement it prior to the manifestation of the syndrome. If such general preventive measures do not succeed, corrective actions should then be directed at individuals, since each one will react differently.

\section{METHODS}

The study is characterized as descriptive and, used a survey design with a quantitative analytic approach. The study was approved by the Ethics Committee of the Federal University of Santa Maria and the School of Penitentiary Services and was conducted in accordance with the National Health Council Resolution no. 196/96, which provides guidelines and norms regulating research involving human beings.

In order to identify the level of workplace wellbeing among workers of the institution, the Labour Well-being Scale, constructed and validated by Paschoal and Tamayo (2008) was used. This survey provides measures of two dimensions: affect and achievement. Affect relates to positive versus negative feelings originating from the work; the second is related to the abilities and potentialities developed in the work that mediate the achievement of life goals (Paschoal \& Tamayo, 2008). Beiriz (2012) explains that the scale is comprised of 30 items divided into three categories: nine are related to positive effect, twelve to negative affect and nine to achievement. Bizzi 
(2016) used Labour Well-being Scale to measure the welfare in the work of the Technical Administrative Servants in Education of the Federal University of Santa Maria. The researcher Sobrinho (2009) also made use of LWBS, aiming to evaluate workplace wellbeing of employees of the Catholic University of Brasilia.

To evaluate the occurrence of Burnout Syndrome in the organization, we used the instrument Spanish Burnout Inventory (SBI), developed by GilMonte (2005) and validated for the Brazilian context by Gil-Monte, Carlotto, and Camera (2010). This questionnaire is comprised of four dimensions: enthusiasm towards job; psychological exhaustion, indolence, and guilt. GilMonte, Rojas, and Ocaña (2009) employed the SBI when studying teachers of early grades of Mexican public schools. On the other hand, Costa et al. (2013) applied in the Brazilian context with university professors from the State of São Paulo.

The research population consisted of public service workers for the Superintendency of Penitentiary Services (Susepe), a government agency of Rio Grande do Sul linked to the Public Security Secretariat. The job categories included in the sample were the Penitentiary Agent (PA), the Administrative Penitentiary Agent (APA) and the Superior Penitentiary Technician (SPT-lawyers, psychologists, and social workers). In view of the impossibility of extending the research to the entire population, we used a stratified sample (Figure 4.1), calculated using the statistical formula for finite population, based on Lopes (2018).

\section{(Figure 4.1)}

STUDY POPULATION AND SAMPLE

\begin{tabular}{lccc}
\hline \multicolumn{1}{c}{ Posts } & Population & $\begin{array}{c}\text { Required } \\
\text { sample }\end{array}$ & $\begin{array}{c}\text { Sample } \\
\text { obtained }\end{array}$ \\
\hline Superintendency of Penitentiary Services & 4557 & 355 & 433 \\
\hline Penitentiary agent & 3671 & 286 & 291 \\
\hline Administrative penitentiary agent & 371 & 29 & 56 \\
\hline Superior penitentiary technician & 515 & 40 & 86 \\
\hline
\end{tabular}

Source: Elaborated by the authors.

The data collection took place in person, from April 20, 2017, to October 3, 2017, through visits to Police Stations, Penitentiaries, Prisons, Penal Institutes, and Electronic Monitoring. Access to the sectors varied according 
to the security protocol of each establishment, as the locations visited ranged from administrative environments to prisons. Thus, sampling did not involve criteria for choosing the individuals, which were characterized as non-probabilistic (Malhotra, 2006). Representatives from all the Police Stations participated in the study, as well as workers linked to the Central Organ and Special Prisons of the Superintendency of Penitentiary Services of the State of Rio Grande do Sul. Regarding the geographical scope of the study, the sample was composed of participants from 22 cities in the State of Rio Grande do Sul. The geographic scope of the study is illustrated in Figure 4.2.

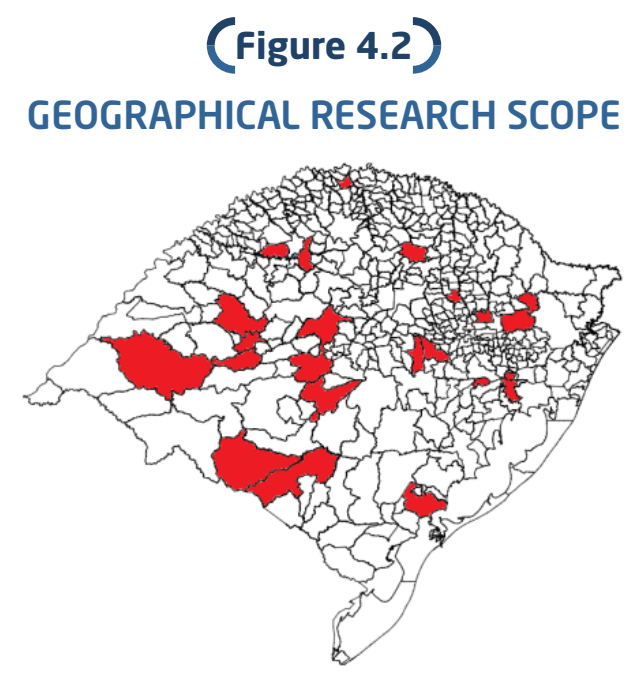

Source: Elaborated by the authors.

Statistical analyses were performed using Statistical Package for Social Sciences version 21 (SPSS) and Statistical Analysis System version 9.1 (SAS) software. The techniques of Descriptive Measures, Cronbach's Alpha, Standardization of Scales, Pearson Correlation Analysis and Correspondence Analysis were used.

\section{RESULTS AND ANALYSES}

The analysis and discussion of the results permeated the use of statistical techniques to measure the levels of workplace wellbeing at and Burnout Syndrome; correlate the constructs, and to associate the levels of the constructs of both themes. 


\subsection{Reliability of the scales in the context of penitentiary workers}

In order to verify the reliability of the instruments in the context in which they were applied, Cronbach's Alpha analysis was used, being one of the most-used tests of internal consistency (Maroco \& Garcia-Marques, 2006). This statistical test was also used by the authors of the scale, presenting significant indexes. This technique revealed acceptable values $(\alpha>0.7)$ for all the constructs of both research instruments, which confirms the internal consistency (Field, 2009; Hair Jr. et al., 2005; Lopes, 2018). Therefore, the analysis of the Cronbach's Alpha indexes of the Labour Wellbeing Scale and of the Spanish Burnout Inventory attest to the statistical reliability of these research instruments for use in the context of prison officials in the State of Rio Grande do Sul.

\subsection{Measuring workplace wellbeing and Burnout Syndrome}

In order to classify the results of the LWBS and SBI constructs into levels, the Standardization of Scales (Lopes, 2018) was used. Following this procedure, the ordinal scale data were transformed to fit a ratio scale, and the categorization of the data took into account the calculation of the sum of the responses of the individuals in relation to the 5-point Likert scales used. Following Lopes (2018) the sums for each dimension can thus be standardized on a scale of 0 to $100 \%$ and then divided into specific categories. In the present study the categories were defined as: low (mean of $0 \%$ to $49.99 \%$ ) and high (mean of $50 \%$ to $100 \%$ ), according to the equation below. This standardization allows the evaluation and comparison of the level reached by each construct of the theoretical model.

$$
S p_{i}=100 *\left(\frac{S U M-M I N I M U M}{M A X I M U M-M I N I M U M}\right), \mathrm{i}=1,2 \text { e } 3 .
$$

where:

$S p_{i}=$ standardized score for dimension $\mathrm{i}$;

$\mathrm{i}=$ number of dimensions;

SUM = sum of valid answers;

MINIMUM = smallest possible sum of valid answers;

MAXIMUM $=$ highest possible number of valid answers. 
Each of the three dimensions of the LWBS must be measured and interpreted differently since each relates differently to workplace wellbeing. According to Paschoal and Tamayo (2008), the creators of the instrument, the full presence of workplace wellbeing is evident from the combined result of a high score for positive constructs and achievement and a low score for the negative effects. This combined score approach was applied by Sobrinho (2009), in a study on employees of the Catholic University of Brasilia, as proposed by Gil-Monte, Carlotto, and Câmara (2010) using the two profiles to characterize and analyzing burnout.

Profile 1 refers to the emergence of a set of feelings and behaviors related to work stress, which causes a moderate form of malaise, but does not incapacitate the individual to exercise his work, although he can perform it better form. This profile 1 is shown by the presence of high enthusiasm towards job with high levels of psychological exhaustion and indolence. Profile 2 defines the classic cases most impaired by the development of Burnout Syndrome, including, in addition to symptoms already recovered, feelings of guilt (Gil-Monte, 2005, p. 142).

Figure 5.2.1 compares the mean values of each construct for workplace wellbeing and Burnout Syndrome in relation to the low and high levels.

(Figure 5.2.1)

CONSTRUCTION LEVELS

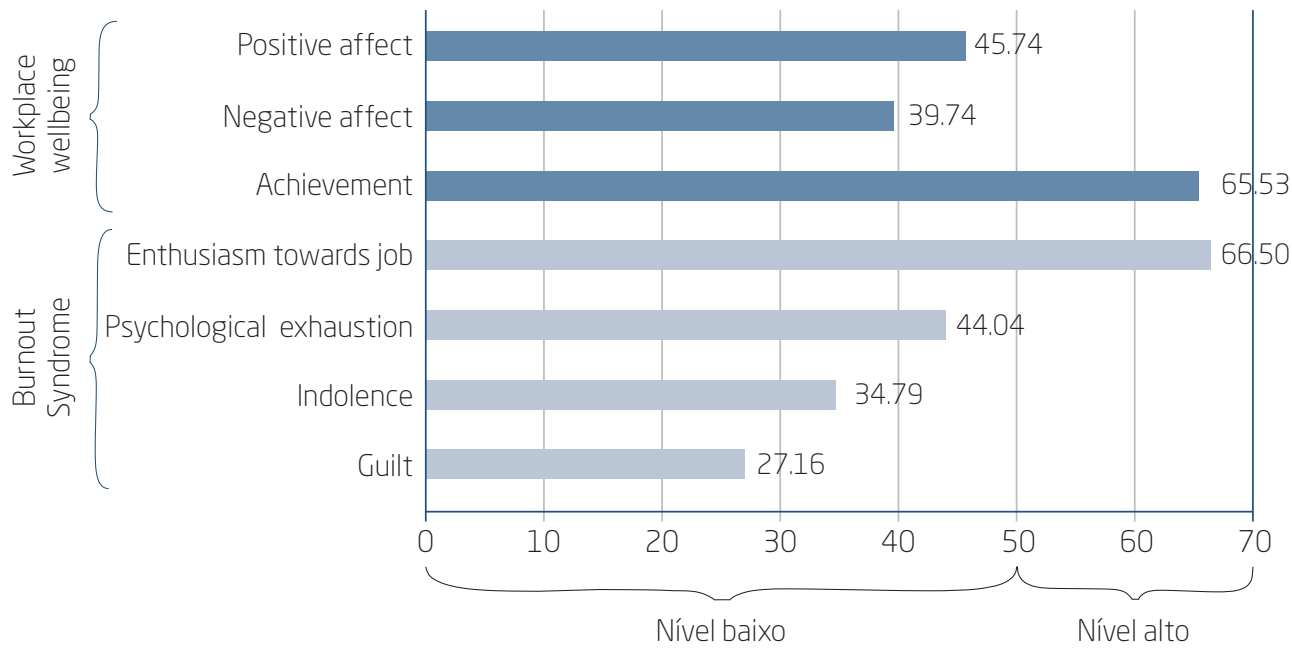

Source: Elaborated by the authors 
Results show that workplace wellbeing is only partially present, as seen in the low score for Positive affect (45.74). Argolo and Araújo (2004, p. 165) affirm that workers' subjective assessment of workplace wellbeing depends on "how much their psychosocial environment gives them opportunities for positive experiences, how these are perceived and how they are harnessed." Similarly, Sonnentag (2002) argues that workers whose workplace needs are satisfied are more productive. Regarding Burnout Syndrome, it is inferred that both Profile 1 (Work Stress) and Profile 2 (Burnout Syndrome) do not exist in the general analysis of the sample, as established by Gil-Monte, Carlotto, and Câmara (2010). This result is consistent with that found by Gil-Monte, Rojas, and Ocaña (2009) for primary school teachers of public schools. Also with an identical combination at the construct levels is the study by Costa et al. (2013), carried out with university professors from the State of São Paulo, Brazil.

Thus, the results are in line with those of Bonez, Dal Moro and Sehnem's (2013), in which prison workers were found to have good mental health conditions and low levels of stress, in addition to showing satisfaction with the profession. In cases of results such as these, it is assumed that the institution provides their workers with adequate labor structure and resources for the effective execution of their activities in a context which possibly subjects them to severe stress conditions (Neves, Oliveira, \& Alves, 2014). According to Schaufeli (2012), with greater involvement and engagement on the part of servers comes greater productivity and concentration in the work.

With this information in mind, strategies can be implemented to improve, maintain or correct the scores for each construct. Makikangas and Kinnunen (2003) showed that enduring stressful work conditions compromise the perception of workplace wellbeing. However, the institution must be specific when implementing actions, avoiding unnecessary efforts. This need for precision provides the rationale for the analysis of the items that make up the constructs. We calculated the Mean $(\bar{x})$ and Standard Deviation (s) of each variable, so that while a high mean score for some constructs suggests well-being. Thus, the constructs were grouped as positive (positive affects, achievement, and enthusiasm towards the job) and negative (negative affects, psychological exhaustion, indolence, and guilt). To evaluate the variables, these were standardized and categorized as weaknesses, opportunities for improvement and strengths. In Figures 5.2.2 and 5.2.3 the respective variables. 


\section{(Figure 5.2.2)}

VARIABLES OF CONSTRUCTS WITH POSITIVE IMPACTS

\begin{tabular}{|c|c|c|c|c|}
\hline & \multirow{2}{*}{ Variable } & \multirow{2}{*}{ Construct } & \multicolumn{2}{|c|}{ Statistics } \\
\hline & & & $(\bar{x})$ & $(s)$ \\
\hline \multicolumn{5}{|c|}{ Strong points } \\
\hline 22 & I develop skills that I consider important & Achievement & 4.29 & 0.84 \\
\hline 30 & I overcome challenges & Achievement & 3.92 & 0.95 \\
\hline 10 & I think my work gives me positive things & Enthusiasm towards job & 3.72 & 0.99 \\
\hline 28 & I do what I really like to do & Achievement & 3.70 & 1.12 \\
\hline 15 & My work is rewarding & Enthusiasm towards job & 3.67 & 1.04 \\
\hline 1 & My work represents a stimulating challenge for me & Enthusiasm towards job & 3.65 & 1.01 \\
\hline 19 & I feel fulfilled with my work & Enthusiasm towards job & 3.64 & 1.06 \\
\hline 26 & I see the results that I value & Achievement & 3.63 & 1.01 \\
\hline 5 & I see my work as a source of personal fulfillment & Enthusiasm towards job & 3.62 & 1.07 \\
\hline 25 & I express what's best about me & Achievement & 3.54 & 1.08 \\
\hline 29 & $\begin{array}{l}\text { I have made progress towards the goals I have set for } \\
\text { my life }\end{array}$ & Achievement & 3.50 & 0.98 \\
\hline 27 & I carry out activities that utilize my abilities & Achievement & 3.50 & 1.04 \\
\hline 24 & I realize my potential & Achievement & 3.40 & 1.10 \\
\hline \multicolumn{5}{|c|}{ Opportunities for improvement } \\
\hline 3 & Willing & Positive affect & 3.21 & 1.03 \\
\hline 23 & I get rewards important to me & Achievement & 3.11 & 1.10 \\
\hline 13 & Happy & Positive affect & 2.92 & 1.05 \\
\hline 1 & Joyful & Positive affect & 2.91 & 0.96 \\
\hline 4 & Content & Positive affect & 2.89 & 1.01 \\
\hline 19 & Proud & Positive affect & 2.88 & 1.24 \\
\hline 8 & Cheered up & Positive affect & 2.77 & 1.01 \\
\hline 21 & Quiet & Positive affect & 2.71 & 1.14 \\
\hline 11 & Enthusiastic & Positive affect & 2.61 & 1.07 \\
\hline 17 & Excited & Positive affect & 2.56 & 1.07 \\
\hline
\end{tabular}

Source: Elaborated by the authors.

As shown in Figure 5.2.2, the strengths were mainly relevant to skill development, overcoming challenges, and the expectation of the individual 
to achieve certain work goals for personal and professional fulfillment. Waterman (1993) mentions that workplace wellbeing can be considered as the perception of the development of potentials and the advancement of life goals. The variables that were figured as strengths belong to the achievement and enthusiasm towards job constructs. At this point, individual engagement with work can also be a contributing factor to this outcome. According to Schaufeli, Bakker, and Salanova (2006), having a greater sense of energy and enthusiasm for the work tends to minimize the adverse effects of negative work conditions.

\section{(Figure 5.2.3)}

\section{VARIABLES OF CONSTRUCTS WITH NEGATIVE IMPACTS}

\begin{tabular}{|c|c|c|c|}
\hline \multirow{2}{*}{ Variable } & \multirow{2}{*}{ Construct } & \multicolumn{2}{|c|}{ Statistics } \\
\hline & & $(\bar{x})$ & $(s)$ \\
\hline \multicolumn{4}{|c|}{ Opportunities for improvement } \\
\hline 18 I feel emotionally worn out & Psychological exhaustion & 3.07 & 1.15 \\
\hline 17 I feel physically tired at work. & Psychological exhaustion & 3.00 & 1.12 \\
\hline 12 Anxious & Negative affect & 2.96 & 1.22 \\
\hline 18 Tense & Negative affect & 2.85 & 1.28 \\
\hline $\begin{array}{l}\text { I think a lot of people I have to deal with in my work are } \\
\text { unbearable }\end{array}$ & Indolence & 2.76 & 1.18 \\
\hline 5 Riled up & Negative affect & 2.68 & 1.21 \\
\hline 15 Troubled & Negative affect & 2.66 & 1.23 \\
\hline 14 Frustrated & Negative affect & 2.64 & 1.33 \\
\hline 12 I feel pressured at work & Psychological exhaustion & 2.62 & 1.18 \\
\hline 10 Impatient & Negative affect & 2.61 & 1.22 \\
\hline $\begin{array}{l}\text { I think the people I have to deal with at work are } \\
\text { unpleasant }\end{array}$ & Indolence & 2.60 & 1.04 \\
\hline 16 Nervous & Negative affect & 2.58 & 1.24 \\
\hline 2 I do not like seeing certain people at work & Indolence & 2.53 & 1.09 \\
\hline 9 Upset & Negative affect & 2.53 & 1.14 \\
\hline $\begin{array}{l}4 \text { I am worried about the way I have treated certain people } \\
\text { at work }\end{array}$ & Guilt & 2.41 & 1.03 \\
\hline $\begin{array}{l}14 \text { I label or classify the people I relate to at work according } \\
\text { to their behavior }\end{array}$ & Indolence & 2.39 & 1.07 \\
\hline
\end{tabular}




\section{(Figure 5.2.3 (conclusion))}

VARIABLES OF CONSTRUCTS WITH NEGATIVE IMPACTS

\begin{tabular}{|c|c|c|c|}
\hline \multirow{2}{*}{ Variable } & \multirow{2}{*}{ Construct } & \multicolumn{2}{|c|}{ Statistics } \\
\hline & & $(\bar{x})$ & $(s)$ \\
\hline 8 I think I am saturated with my work & Psychological exhaustion & 2.36 & 1.15 \\
\hline $\begin{array}{l}7 \text { I think I treat with indifference some people that I have } \\
\text { to deal with in my work }\end{array}$ & Indolence & 2.22 & 1.08 \\
\hline $\begin{array}{l}16 \text { I think I should apologize to someone for my behavior } \\
\text { at work }\end{array}$ & Guilt & 2.11 & 0.86 \\
\hline 20 I feel bad for some things I said at work & Guilt & 2.10 & 0.79 \\
\hline 20 Angry & Negative affect & 2.09 & 1.17 \\
\hline 9 I feel guilty for some of my attitudes at work & Guilt & 2.08 & 0.91 \\
\hline 7 Bored & Negative affect & 2.08 & 1.17 \\
\hline 6 Depressed & Negative affect & 2.04 & 1.15 \\
\hline 11 I appreciate being ironic with some people in my work & Indolence & 1.89 & 1.03 \\
\hline 13 I have regrets about some of my behaviors at work & Guilt & 1.73 & 0.84 \\
\hline \multicolumn{4}{|l|}{ Weak point } \\
\hline 2 Worried & Negative affect & 3.35 & 1.12 \\
\hline
\end{tabular}

Source: Elaborated by the authors.

Regarding opportunities for improvement (Figure 5.2.3), all variables should be taken into consideration by the management of SUSEPE, especially those responses with lower mean scores, such as excitement, enthusiasm, tranquility and work animation (positive effect). In Bizzi's study (2013), carried out with Administrative Technicians in Education at UFSM, the excitement variable also presented the lowest scores. Likewise, items with higher mean scores for negative constructs may also reveal weaknesses, such as factors related to emotional and physical exhaustion (psi), as well as feelings of anxiety and tension at work (negative effect).

Also included as alerts are the mean scores for the variables related to the indolence and guilt constructs. These represent feelings of remorse for attitudes and behavior at work and expressions of indifference and cynicism towards the people at work. A similar result was found in the study by Justo and Benevides-Pereira (2011), who analyzed the levels of stress and Burnout among penitentiary workers, also showing the emotional exhaustion dimension as scoring the highest among indicators of the syndrome. The 
indicators related to the psychological exhaustion construct may serve as an alert for management because they represent factors predating occupational stress (Santos \& Cubas, 2012).

Only one variable was classified as a weak point, which represents the feeling of concern. In studying job satisfaction of the military police of the State of Rio Grande do Sul, Almeida (2015) also found an opportunity to positively address those aspects that lead to worry at work. However, the routine of penitentiary workers can lead to an ongoing sense of concern, which may harm the health of individuals (Tschiedel \& Monteiro, 2013; Rumin, 2006). Consequently, we sought to deepen our data analysis by cross-validating through correlation and association techniques.

\subsection{Correlations between constructs}

Pearson's Correlation Analysis was used to test for relationships between all possible pairs of constructs of workplace wellbeing and Burnout Syndrome, all of which were found to be significant ( $p$-value $\leq 0.05$ ). The Pearson correlation coefficient $(r)$ is a measure of the strength of the relationship between two variables and is classified as: null (0.00); very weak (0.01 to $0.20)$; weak (0.21 to 0.40$)$; moderate ( 0.41 to 0.60$)$; strong (0.61 to 0.80 ); very strong ( 0.81 to 0.99$)$; and perfect $(r=1.00)$. Our results are displayed in Figure 5.3.1, with those values representing moderate and or stronger correlation in bold. Positive values indicate a direct relationship, negative ones an inverse relationship (i.e. a high value in one variable is associated with a lower value in the other). 


\section{(Figure 5.3.1)}

\section{SYNTHESIS OF CORRELATIONS BETWEEN THE SWB AND BURNOUT CONSTRUCTS}

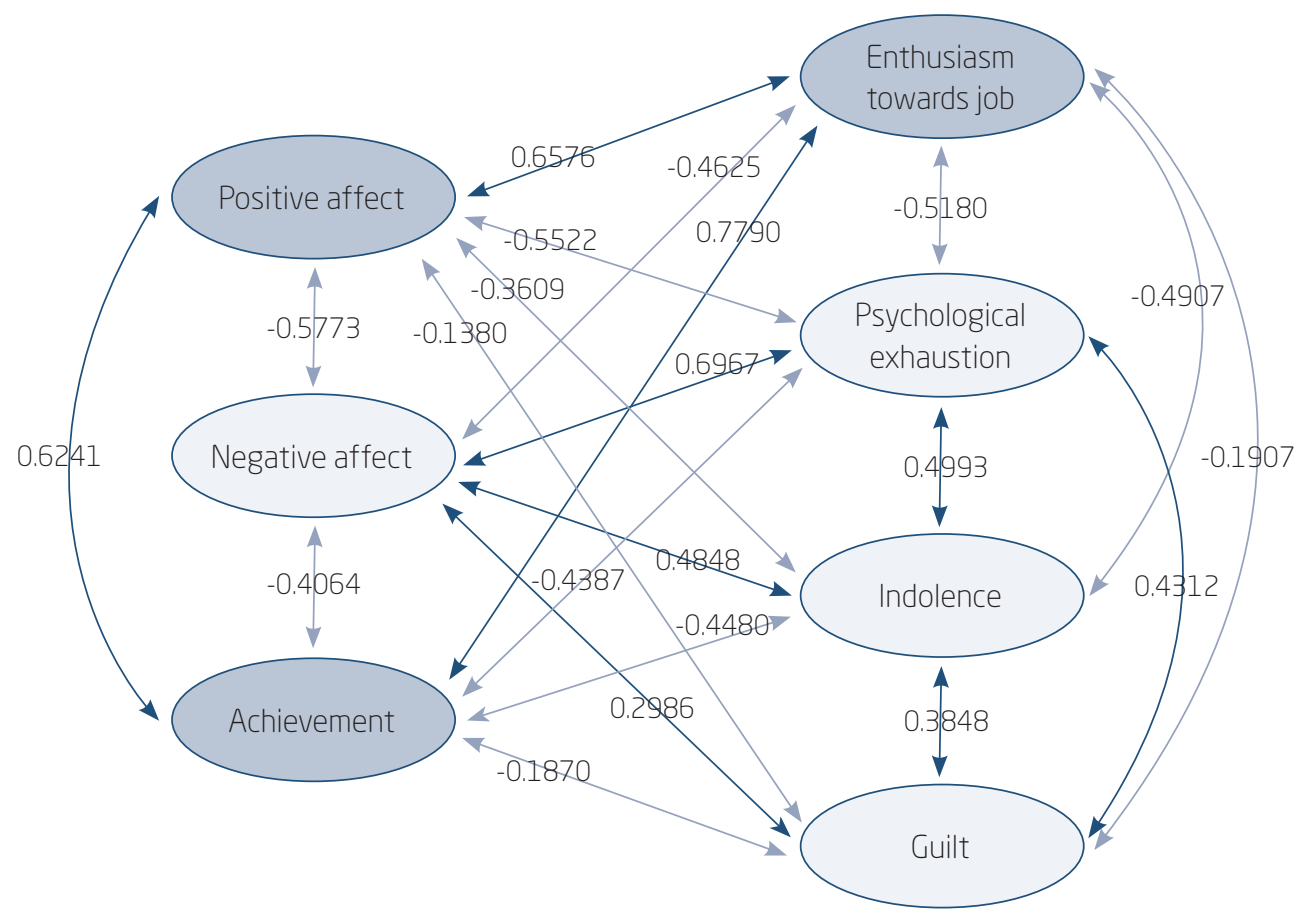

Source: Elaborated by the authors.

As illustrated in Figure 5.3.1 for the comparisons of the constructs of workplace wellbeing, there was a strong correlation between beneficial feelings for the organization (positive affects), and attitudes expressed about the work environment, particularly as related to the development of skills and professional growth (achievement). Regarding the comparisons within the constructs associated with Burnout Syndrome, it is clearly evident the individual's experience of achievement at work, an indicator of personal and professional fulfillment, (enthusiasm towards job) is negatively associated with the presence of emotional and physical stress resulting from work activities (psychological exhaustion).

In comparing the respective constructs of workplace wellbeing and Burnout Syndrome, our results show that beneficial feelings towards the organization (positive affects) are negatively associated with emotional and physical exhaustion due to the work activity. In the study by Almeida (2015), the military police of Rio Grande do Sul gauchos demonstrated an inverse 
relationship between Satisfaction at Work and the experience of Occupational Stress. This result corroborates those of the present study since the dispersion of the variables indicates an inversely proportional relationship between the themes.

\subsection{Associations between levels of constructs}

As stated earlier, the study showed that overall, workplace wellbeing is partially present in the routine of penitentiary servants and that there was no convincing evidence of occupational stress or Burnout Syndrome. Although these results represent the general picture among the penitentiary workers studied, there are portions of the data that deserve further study, taking into account the relevant combinations demonstrated between the levels of the constructs. According to Rudow (1999) and Kaur, Chodagiri, and Reddi (2013) identifying symptoms of burnout in an employee of one institution does not guarantee burnout in other workers, because the progress of this disease occurs in a unique way in each individual and its effects may take years to be perceived.

To aid interpretation and deepen understanding of results, we performed a Correspondence Analysis in which related scores for workplace wellbeing and Burnout Syndrome constructs were grouped. The variables used in the analysis were the frequencies of responses of the workers to the different constructs, organized in three combinations representing. According to Carvalho and Struchiner (1992, p. 288), this technique is indicated when the goal is to identify all possible relevant relationships within a set of variables or constructs. Figure 5.4.1 presents the different combinations of related constructs.

(Figure 5.4.1)

COMBINATIONS OF CONSTRUCT LEVELS

\begin{tabular}{llccc}
\hline & \multicolumn{4}{c}{ Combinations of levels } \\
\cline { 2 - 3 } & 1 & 2 & 3 & 4 \\
\hline Constructs & \multicolumn{2}{c}{ Workplace wellbeing } & \\
\hline Positive affect & Low & High & Low & \\
\hline Negative affect & Low & Low & High & Others \\
\hline Achievement & High & High & Low & \\
\hline
\end{tabular}




\section{(Figure 5.4 .1 (conclusion))}

COMBINATIONS OF CONSTRUCT LEVELS

\begin{tabular}{lcccc}
\hline \multirow{2}{*}{ Constructs } & \multicolumn{4}{c}{ Combinations of levels } \\
\cline { 2 - 4 } & 1 & 2 & 3 & 4 \\
\hline Frequency & 99 & 153 & 57 & 124 \\
\hline Percentage & 22.86 & 35.33 & 13.16 & $28.65 \%$ \\
\hline Enthusiasm towards job & Burnout syndrome & & \\
\hline Psychological exhaustion & High & Low & Low & \\
\hline Indolence & Low & High & High & \\
\hline Guilt & Low & High & High & \\
\hline Frequency & Low & Low & High & \\
\hline Percentage & 226 & 28 & 12 & 167 \\
\hline
\end{tabular}

Source: Elaborated by the authors.

For the combinations under workplace wellbeing, we found that $22.86 \%$ of participants demonstrated the partial presence of workplace wellbeing (Combination 1), $35.22 \%$ of participants experienced well-being in the work environment (Combination 2), while $13.16 \%$ of the penitentiary workers expressed the complete absence of workplace wellbeing (Combination 3). The remaining $28.65 \%$ of participants had other score combinations that did not fall into any of these three categories. 
(Figure 5.4.2)

ANALYSIS OF CORRESPONDENCE OF LEVELS

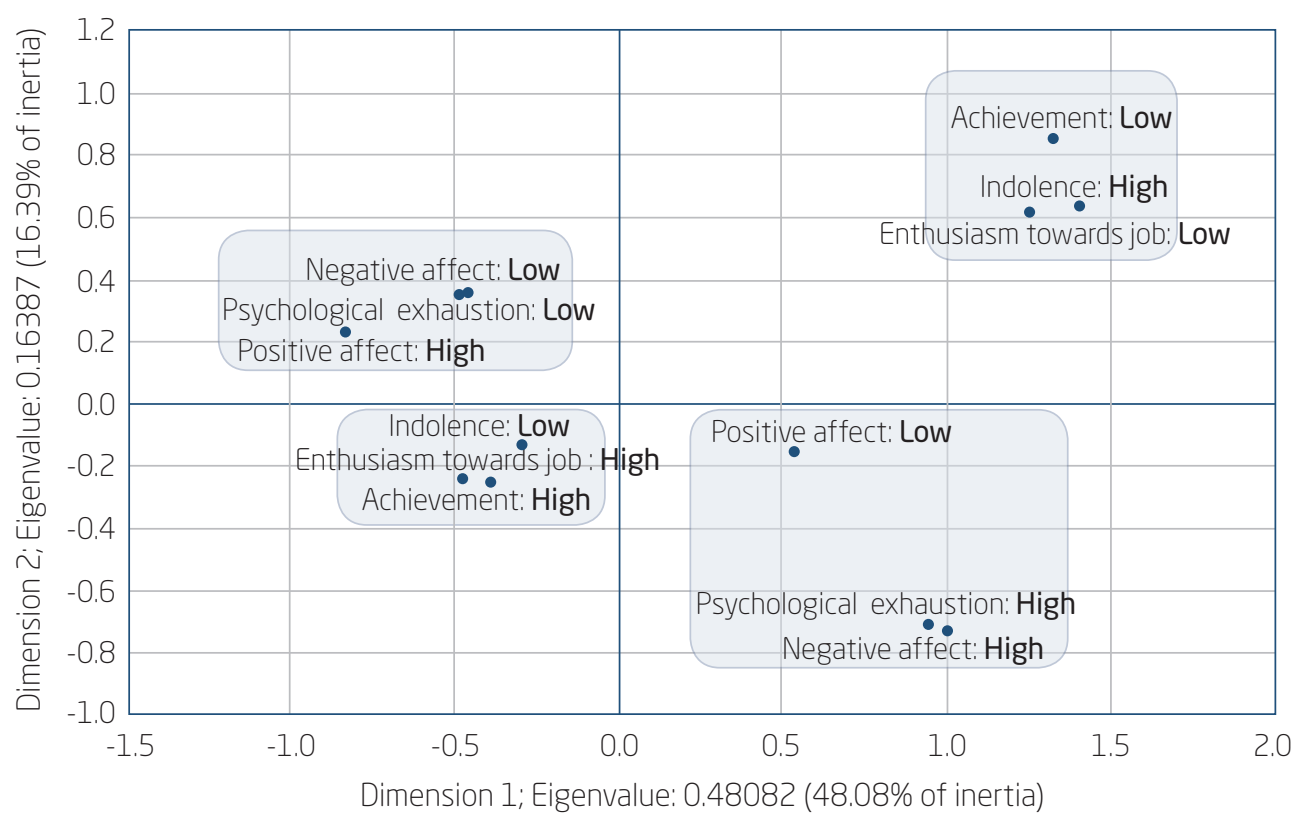

Source: Elaborated by the authors.

With regard to Burnout Syndrome, we see that Combination 1, corresponding to the absence of Occupational Stress and Burnout Syndrome, was the general trend, that is, $52.19 \%$ of the penitentiary workers sampled did not experience this illness. Combination 2, indicative of Profile 1 (experience of workplace stress) applied to $6.47 \%$ of the participants. However, being Profile 1, this stress is not yet detrimental, nor does it make it impossible for the individual to perform his/her functions. According to Bianchi (2001), stress can have a positive effect, as when the individual perceives the stressful stimulus as a challenge. Finally, Combination 3 represents what the authors defined as Profile 2 - Burnout Syndrome - and was seen for only $2.77 \%$ of the sample. Unlike stress, which may be linked to positive effects, Burnout Syndrome always has negative outcomes on professional and personal life (Benevides-Pereira, 2002). According to Carvalho and Magalhães (2011, p. 204) "Burnout usually leads to deterioration of physical and emotional well-being".

In addition, some constructs showed simultaneous levels, Figure 5.4.2 summarizes the significant associations between the workplace wellbeing and Burnout constructs, with reference to their respective levels (low or 
high). Guilt was the only construct not associated with any other, and therefore it does not appear in Figure 5.4.2. The results have been grouped in a manner intended to guide strategy development. Therefore, when implementing an action to increase effective scores, for example, parallel measures should be taken to decrease psychological exhaustion since these two constructs are inversely correlated. This associative strategy can also be applied with regard to low scores for the constructs of achievement, enthusiasm towards job and indolence, targeting these dimensions simultaneously for an integrated strategy.

\section{CONCLUSIONS}

The present study made it possible to analyze the perspectives of penitentiary service workers for the State of Rio Grande do Sul regarding the relationship between the indicators of workplace wellbeing and Burnout Syndrome. The SUSEPE context pointed to the partial existence of workplace wellbeing, being experienced by $35.33 \%$ of the prison staff while being absent for $13.16 \%$ of the participant sample. Also, in general, we verified the absence of occupational stress sufficient to cause Burnout Syndrome among $52.19 \%$ of the penitentiary service workers. Work-related stress was perceived in only $6.47 \%$ of the workers, and only $2.77 \%$ showed evidence that they were experiencing burnout. Although these results indicate no need for concern for workers in this particular context, these results may be useful for guiding the development of preventive strategies targeting those constructs with less satisfactory results.

The demonstration of the significance of the correlations between all pairs of constructs that involve the two themes enables SUSEPE to understand how a specific action directed at a specific construct also impacts the others. The results indicate that when the sense of achievement at work is high, so is the enthusiasm towards the job. Likewise, when the positive effect is high, the psychological exhaustion tends to be low.

The association of related construct scores revealed four combinations, each with three constructs. The associated constructs were negative affects, psychological exhaustion, positive affects, and indolence, enthusiasm towards job, achievement. Only the guilt construct did not show any associations with other constructs. Thus, the results enable SUSEPE to visualize how the levels for each construct manifest simultaneously in the sample of workers studied. This information can be applied to creating a set 
of actions directed to the associated constructs, being aware that each individual will score differently in each construct.

Regarding the limitations of this study, it is important to highlight a quantitative approach, the difficulty of comparison with other similar scientific studies, and the cross-sectional aspect. Further studies in the penitentiary context are indicated, such as investigation on the effects of organizational commitment and engagement in work and work-family conflict. In conclusion, these considerations and limitations listed serve as a starting point for the development of new studies on workplace wellbeing and Burnout Syndrome and the public of penitentiary servers.

\section{BEM-ESTAR NO TRABALHO E SÍNDROME DE BURNOUT: FACES OPOSTAS NO LABOR PENITENCIÁRIO}

\section{$\int$ RESUMO}

Objetivo: O objetivo deste estudo é analisar a perspectiva dos servidores penitenciários do estado do Rio Grande do Sul no que tange à relação entre os componentes do bem-estar no trabalho e os da síndrome de burnout.

Originalidade/valor: Profissionais da área da segurança pública convivem diariamente com uma pluralidade de sentimentos, uma vez que desempenham suas atividades em meio a elevados níveis de tensão. Nesse ramo está inserida a Superintendência dos Serviços Penitenciários do Estado do Rio Grande do Sul (Susepe), cujo ambiente laboral, em cada um de seus estabelecimentos prisionais, pode revelar faces opostas no cotidiano dos servidores penitenciários, como o bem-estar no trabalho e a síndrome de burnout.

Design/metodologia/abordagem: Fez-se uso de uma pesquisa descritiva, do tipo survey, com uma abordagem quantitativa. A amostra foi não probabilística e constituída de 433 respondentes.

Resultados: Os resultados da pesquisa indicaram que o bem-estar no trabalho está parcialmente presente no cotidiano dos servidores penitenciários e que não foram evidenciados estresse laboral e síndrome de burnout. Quanto às correlações entre os constructos, todas demonstraram ser significantes. Os resultados revelaram quatro associações signi- 
ficativas entre os níveis dos constructos de bem-estar no trabalho e os de síndrome de burnout.

\section{PALAVRAS-CHAVE}

Comportamento organizacional. Bem-estar no trabalho. Síndrome de burnout. Servidor penitenciário. Susepe.

\section{$\int$ REFERENCES}

Abreu, K. L., Stoll, I., Ramos, L. S., Baumgardt, R. A. \& Kristensen, C. H. (2002). Estresse ocupacional e Síndrome de Burnout no exercício profissional da psicologia. Psicologia: Ciência e Profissão, 22(2). doi:10.1590/S14 14-98932002000200004

Accardo, É. M. (2013). As relações entre conflito trabalho-família, bem-estar subjetivo e bem-estar no trabalho (Master's thesis). Universidade Metodista de São Paulo, São Bernardo do Campo, SP, Brazil.

Albuquerque, A., \& Tróccoli, B. T. (2004). Desenvolvimento de uma escala de bem-estar subjetivo. Psicologia: Teoria e Pesquisa, 20, 153-164. doi:10.15 90/S0102-37722004000200008

Almeida, D. M. (2015). Satisfação no trabalho e estresse ocupacional na perspectiva dos policiais militares do estado do Rio Grande do Sul (Master's thesis). Universidade Federal de Santa Maria, Santa Maria, RS, Brazil.

Argolo, J. C. T., \& Araújo, M. A. D. (2004). O impacto do desemprego sobre o bem-estar psicológico dos trabalhadores da cidade de Natal. Revista de Administração Contemporânea, 8(4), 161-182. doi:10.1590/S1415-65552004 000400009

Bakker, A. B., \& Demerouti, E. (2013). La teoría de las demandas y los recursos laborales. Journal of Work and Organizational Psychology, 29, 107-115. doi:10.5093/tr2013a16

Beiriz, L. P. L. (2012). Bem-estar e desempenho no trabalho: Estudo de caso em uma empresa de comunicação (Master's thesis). Fucape, Vitória, ES, Brazil.

Benevides-Pereira, A. M. T. B (Org.). (2002). Burnout: Quando o trabalho ameaça o bem-estar do trabalhador (3rd ed.). São Paulo, SP: Casa do Psicólogo. 
Bianchi, E. R. F. (2001). Conceito de stress: Evolução histórica. Nursing, 4(39), 16-19.

Bizzi, L. (2013). O bem-estar no trabalho e suas relações com suporte e comprometimento organizacional afetivo: Estudo de caso na Universidade Federal de Santa Maria (UFSM) (Master's thesis). Universidade Federal de Santa Maria, Santa Maria, RS, Brazil.

Bonez, A., Dal Moro, E., \& Sehnem, S. B. (2013). Saúde mental de agentes penitenciários de um presídio. Revista Psicologia Argumento, 31 (74), 507-517. doi:10.7213/psicol.argum.31.074.AO05

Botelho, R. D., \& Paiva, K. C. M. (2011). Comprometimento organizacional: Um estudo no Tribunal de Justiça do Estado de Minas Gerais. Revista de Administração Pública, 45(5), 1249-1283.

Brasil. Lei n. 8.213, de 24 de julho de 1991 (1991). Dispõe sobre os Planos de Benefícios da Previdência Social e dá outras providências. Diário Oficial da União, Brasília, DF, 25 jul. 1991, 9-19.

Brasil. Ministério da Saúde. Portaria n. 1.339, de 18 de novembro de 1999. (1999). Instituir a Lista de Doenças relacionadas ao Trabalho.

Carvalho, C. G., \& Magalhães, S. R. (2011). Síndrome de Burnout e suas consequências nos profissionais de enfermagem. Revista da Universidade Vale do Rio Verde, 9(1), 200-210.

Carvalho, M. S., \& Struchiner, C. J. (1992). Análise de correspondência: Uma aplicação do método à avaliação de serviços de vacinação. Cad. Saúde Públ., 8(3), 287-301.

Costa, L. S., Gil-Monte, P. R., Possobon, R. F. \& Ambrosano, G. M. B. (2013). Prevalência da Síndrome de Burnout em uma amostra de professores Universitários Brasileiros. Psicologia: Reflexão e Crítica, 26(4), 636-642. doi:10. 1590/S0102-79722013000400003

Dessen, M. C., \& Paz, M. G. T. (2010). Bem-estar pessoal nas organizações: O impacto de configurações de poder e características de personalidade. Psicologia: Teoria e Pesquisa, 26(3), 549-556. doi:10.1590/S0102-37722010 000300018

Diener, E., Suh, E., \& Oishi, S. (1997). Recent findings on subjective well being. Indian Journal of Clinical Psychology, 24, 25-41.

Faro, A., \& Pereira, M. E. (2013). Medidas do estresse: Uma revisão narrativa. Psicologia, Saúde \& Doenças, 14(1), 101-124.

Ferraz, F. C., Francisco, F. R., \& Oliveira, C. S. (2014). Estresse no ambiente de trabalho. Archives of Health Investigation, 3(5), 1-8. 
Field, A. (2009). Descobrindo a estatística usando o SPSS (2nd ed.). Porto Alegre, RS: Artmed.

Galinha, I., \& Ribeiro, J. L. P. (2005). História e evolução do conceito de bem-estar subjectivo. Psicologia, Saúde \& Doenças, 6(2), 203-214.

Gil-Monte, P. R. (2005). El síndrome de quemarse por el trabajo (Burnout): Una enfermedad laboral en la sociedad del bienestar. Madrid, ES: Pirámide.

Gil-Monte, P. R., Carlotto, M. S., \& Câmara, S. G. (2010). Validação da versão brasileira do "Cuestionario para la Evaluación del Síndrome de Quemarse por el Trabajo” em professores. Revista Saúde Pública, 44(1), 140-147. doi:10.1590/S0034-89102010000100015

Gil-Monte, P. R., Rojas, S. U., \& Ocaña, J. I. S. (2009). Validez factorial del Cuestionario para la Evaluación del Síndrome de Quemarse por el Trabajo (CESQT) en uma muestra de maestros mexicanos. Salud Mental, $31,205-214$.

Hair Jr., J. F., Badin, H., Money, A. H., \& Samouel, F. (2005). Fundamentos de métodos de pesquisa em administração. Porto Alegre, RS: Bookman.

Hakanen, J. J., Perhoniemi, R., \& Toppinen-Tanner, S. (2008). Positive gain spirals at work: From job resources to work engagement, personal initiative and work-unit innovativeness. Journal of Vocational Behavior, 73, 78-91. doi:10.1016/j.jvb.2008.01.003

Jacobsen, G. (2017/07/31). Gestão Sartori chega ao $20^{\circ}$ mês consecutivo de parcelamento dos salários. Correio do Povo. Retrieved from http://www. correio dopovo.com.br/Noticias/Politica/2017/7/624390/Gestao-Sartorichega-ao-20-mes-consecuti vo-de-parcelamento-dos-salarios

Justo, T., \& Benevides-Pereira, A. M. (2011). O Burnout em agentes penitenciários de uma cidade do interior do Brasil. Anais do Congresso Internacional de Psicologia, UEM. Maringá, PR, Brasil, 1.

Kaur, R., Chodagiri, V. K., \& Reddi, N. K. (2013). A psychological study of stress, personality and coping in police personnel. Indian Journal of Psychological Medicine, 35(2), 141-147. doi:10.4103/0253-7176.116240

Leiter, M. P., Bakker, A. B., \& Maslach, C. (2014). Burnout at work. New York, NY: Taylor \& Francis.

Lipp, M. E. N. (2000). O Stress está dentro de você (2nd ed.). São Paulo, SP: Contexto.

Lopes, L. F. D. (2018). Métodos quantitativos aplicados ao comportamento organizacional. Santa Maria: Voix. 
Makikangas, A., \& Kinnunen, U. (2003). Psychosocial work stressors and well-being: Selfesteem and optimism as moderators in a one-year longitudinal sample. Personality and Individual Differences, 35, 537-557. doi:10.1016/S0191-8869(02)00217-9

Malhotra, N. K. (2006). Pesquisa de marketing: Uma orientação aplicada (4th ed.). Porto Alegre, RS: Bookman.

Maroco, J., \& Garcia-Marques, T. (2006). Qual a fiabilidade do alfa de Cronbach? Questões antigas e soluções modernas? Laboratório de Psicologia, 4(1), 65-90.

Maslach, C. (2003). Job Burnout: New directions in research and intervention. Current Directions in Psychological Science, 12(5), 189-192. doi:10.1111/14678721.01258

Maslach, C., \& Jackson, S. E. (1981). The measurement of experienced Burnout. Journal of Occupational Behaviour, 2, 99-113. doi:10.1002/job.403 0020205

Maslach, C., Schaufelli, W. B., \& Leiter, M. P. (2001). Job Burnout. Annual Review of Psychology, 52(1), 397-422. doi:10.1146/annurev.psych.52.1.397

Ministério Público. (2016). A visão do Ministério Público sobre o sistema prisional brasileiro. Brasília, DF: CNMP.

Monteiro, J. K., Dalagasperina, P., \& Quadros, M. O. (2012). Professores no limite: O estresse no trabalho do ensino privado no Rio Grande do Sul. Porto Alegre, RS: Carta editora.

Neves, V. F., Oliveira, Á. F., \& Alves, P. C. (2014). Síndrome de Burnout: Impacto da satisfação no trabalho e da percepção de suporte organizacional. Psico, 45(1), 45-54. doi:10.15448/1980-8623.2014.1.12520

Novo, R. F. (2003). Para além da eudaimonia: O bem-estar psicológico em mulheres na idade adulta avançada. Textos Universitários de Ciências Sociais e Humanas. Coimbra, PT: Fundação Calouste Gulbenkian e Fundação para a Ciência e a Tecnologia.

Paschoal, T. (2008). Bem-estar no trabalho: Relações com suporte organizacional, propriedades axiológicas e oportunidades de alcance de valores pessoais no trabalho (Doctoral dissertation). Institute of Psychology, Universidade de Brasília, Brasília, DF, Brazil.

Paschoal, T., \& Tamayo, A. (2008). Construção e validação da escala de bem-estar no trabalho. Avaliação Psicológica, 7(1), 11-22.

Rio Grande do Sul (2009). Lei Complementar n. 13.259, de 20 de outubro de 2009. 
Rothbard, N., \& Edwards, J. R. (2000). Mechanisms linking work and family: Clarifying the relationship between work and family constructs. The Academy of Management Review, 25(1), 178-199. doi:10.2307/259269

Rudow, B. (1999). Stress and Burnout in the teaching profession: European studies, issues, and research perspectives. Cambridge University Press, 38-58. doi:10.1017/CBO9780511527784.004

Rumin, C. R. (2006). Sofrimento na vigilância prisional: O trabalho e a atenção em saúde mental. Psicologia, Ciência e Profissão, 26(4), 570-581. doi:10. 1590/S1414-98932006000400005

Ryan, R. M., \& Deci, E. L. (2001). On happiness and human potentials: a review of research on hedonic eudaimonic well-being. Annual Review Psychology, 52, 141-166. doi:10.1146/annurev.psych.52.1.141

Sant'anna, L. L., Paschoal, T., \& Gosendo, E. E. M. (2012). Bem-estar no trabalho: Relações com estilos de liderança e suporte para ascensão, promoção e salários. Revista de Administração Contemporânea, 16(5), 744-764. doi:10.1590/S1415-65552012000500007

Santos, A. S., \& Cubas, M. R. (2012). Saúde coletiva: Linhas de cuidado e consulta em enfermagem. Rio de Janeiro, RJ: Elsevier.

Schaufeli, W.B. (2012). Work engagement: What do we know and where do we go? Romanian Journal of Applied Psychology, 14, 3-10. doi:10.1177/001 3164405282471

Schaufeli, W.B., Bakker, A.B. \& Salanova, M. (2006). The measurement of work engagement with a short questionnaire: A cross-national study. Educational and Psychological Measurement, 66, 701-716.

Siqueira, M. M. M., \& Padovam, V. A. R. (2008). Bases teóricas de bem-estar subjetivo, bem-estar psicológico e bem-estar no trabalho. Psicologia: Teoria ePesquisa,Brasília, 24(2),201-209.doi:10.1590/S0102-37722008000200010

Sobrinho, F. R. (2009). Bem-estar no trabalho, clima social e estratégias de enfrentamento do estresse (Master's thesis). Catholic University of Brasilia, Brasília, DF, Brazil.

Sonnentag, S. (2002). Performance, well-being and self-regulation. In Sonnentag, S. (Ed.). Psychological Management of Individual Performance. Great Britain: John Wiley \& Sons, 405-425. doi:10.1002/0470013419.ch20

Sonnentag, S., \& Bayer, U. V. (2005). Switching off mentally: Predictors and consequences of psychological detachment from work during off-job time. Journal of Occupational Health Psychology, 10, 393-414. doi:10.1037/10768998.10.4.393 
Tschiedel, R. M., \& Monteiro, J. K. (2013). Prazer e sofrimento no trabalho das agentes de segurança penitenciária. Estudos de Psicologia, 18(3), 527-535. doi:10.1590/S1413-294X2013000300013

Waterman, A. S. (1993). Two conceptions of happiness: Contrasts of personal expressiveness (eudaimonia) and hedonic enjoyment. Journal of Personality and Social Psychology, 64(4), 678-691. doi:10.1037/0022-3514.64.4.678

Waterman, A. S., Schwartz, S. J., \& Conti, R. (2008). The implications of two conceptions of happiness (hedonic enjoyment and eudaimonia) for the understanding of intrinsic motivation. Journal of Happiness Studies, 9(1), 41-79. doi:10.1007/s10902-006-9020-7

Weltman, G., Lamon, J., Freedy, E. \& Chartrand, D. (2014). Police department personnel stress resilience training: An institutional case study. Global Advances in Health and Medicinet, 3 (2), 72-79. doi:10.7453/gahmj.2014.015

\section{AUTHOR NOTES}

Jonathan S. Corrêa, Department of Business Administration, Federal University of Santa Maria (UFSM); Luis F. D. Lopes, Department of Engineering, Federal University of Santa Catarina (UFSC); Damiana M. Almeida, Department of Business Administration, Federal University of Santa Maria (UFSM); \& Maria E. Camargo, Department of Engineering, Federal University of Santa Catarina (UFSC).

Jonathan S. Corrêa is now Administrative Technician in Education at Federal University of Pampa (Unipampa); Luis F. D. Lopes is now Teacher at Department of Administrative Sciences from the Federal University of Santa Maria (UFSM); Damiana M. Almeida is now Teacher at Faculty of Health Sciences (SOBRESP); \& Maria E. Camargo is now Professor at University of Caxias do Sul (UCS).

Correspondence concerning this article should be addressed to Jonathan S. Corrêa, Rua Pedro Morais Germany, 374, Bairro Juscelino Kubitschek, Santa Maria, Rio Grande do Sul, Brazil, CEP 97035-620.

E-mail: jonathan.saidelles@gmail.com

EDITORIAL BOARD

Editors-in-chief Janette Brunstein

Silvio Popadiuk

Associated Editor

Luciana Mourão Cerqueira e Silva

Technical Support

Vitória Batista Santos Silva

$\begin{array}{ll}\text { EDITORIAL PRODUCTION } & \\ \text { Publishing Coordination } & \text { Layout Designer } \\ \text { Irina Migliari } & \text { Emap } \\ \text { Copyeditor } & \text { Graphic Designer } \\ \text { Irina Migliari (English) } & \text { Libro } \\ \text { Carlos Villarruel (Portuguese) } & \\ \text { Language Editor } & \\ \text { Daniel de Almeida Leão (English) } \\ \text { Irina Migliari (Portuguese) }\end{array}$

EDITORIAL PRODUCTION

Publishing Coordination

Copyeditor

Irina Migliari (English)

Language Editor

Irina Migliari (Portuguese) 